\title{
C/C複合材料ならびにチラノヘックスの剪断強度の負荷速度依存性
}

\author{
田邊靖博*, 石黒陽介, 赤津 隆, 安田榮一 \\ (平成14年1月17日受理, 平成14年3月28日採択)
}

\section{Strain-Rate Dependence of the Shear Strength of C/C Composites and Tyrannohex}

\author{
Yasuhiro Tanabe*, Yohsuke Ishiguro, Takashi Akatsu and Eiichi Yasuda
}

\begin{abstract}
Inter-laminar shear strengths (ILSSs) of two types of C/C composites and two types of Tyrannohex were measured as a function of strain rate. Charpy impact test machine can be used to measure ILSS for dynamic tensile loading in double notched configuration. ILSS of the unidirectional $\mathrm{C} / \mathrm{C}$ composite was nearly constant at the strain rates ranging from $1.6 \times 10^{-5} / \mathrm{s}$ to $617 / \mathrm{s}$, while that of cross-ply $\mathrm{C} / \mathrm{C}$ composite increased with the rate. On the contrary, ILSSs of the both types of Tyrannohex decreased at the higher strain rates. For the unidirectional $\mathrm{C} / \mathrm{C}$ composite, the crack propagation velocity could be measured using crack gages. The velocity of a crack which appeared between the double notches increased with the strain rate $; 480 \mathrm{~m} / \mathrm{s}$ at $1.6 \times 10^{-5} / \mathrm{s}$ and $1,400 \mathrm{~m} / \mathrm{s}$ at $1.6 \times 10^{-1} / \mathrm{s}$. The propagation velocity of the crack at higher strain rates above $1.6 \times 10^{-1} / \mathrm{s}$ could not be measured, because the crack gages failed to respond to the crack propagation in velocity.
\end{abstract}

KEYWORDS : ILSS, Strain-rate dependence, C/C Composite, Tyrannohex

1.はじめに

炭素襳維強化炭素複合材料 $(\mathrm{C} / \mathrm{C}$ 複合材料) あるいは $\mathrm{SiC} / \mathrm{SiC}$ 複合材料などの長繊維強化セラミック基複合材料は, 次世代エネルギー創製あるいは次世代宇宙航空分野での構 造関連部材としての利用展開に向けた研究が進められてい る。このような環境下では, 準静的な負荷環境ばかりではな く衝撃的な負荷がかかることが予想される。しかし, セラミ ック基複合材料の強度の歪速度依存性に関する研究は非常 に少ない1 2。

繊維強化複合材料は, 繊維配向軸にかかわる強化特性にば かり注目が集まり, 層間剪断強度 (ILSS)のようにマトリック スあるいは界面の特性が重要な力学特性に関する研究は限ら れている。C/C複合材料についても準静的な環境下でのILSS については, 研究報告がなされている3'が, 衝撃的な負荷環境 下でのILSSに関する研究は皆無といえる。

そこで, 本研究では, 一般の材料試験機ならびにシャルピー 衝撃試験機を用いて, 広範な歪速度域にわたる $\mathrm{C} / \mathrm{C}$ 複合材料な らびに $\mathrm{SiC} / \mathrm{SiC}$ 複合材料のILSSの歪速度依存性を測定するこ とを目的とした。

\section{2. 実験方法}

\section{1 試料}

$\mathrm{C} / \mathrm{C}$ 複合材料として,プリフォームドヤーン法で作製した株 式会社アクロス製一方向強化材料 (UD-C/C と略記) ならびに $0^{\circ} 190^{\circ}$ 直交積層強化材料 (CP-C/C と略記) を用いた。 $\mathrm{SiC}$ 系 複合材料として宇部興産株式会社製一方向強化 (UD-Tyrano と略記) ならびに直交積層強化チラノヘックス (CP-Tyranoと 略記)を用いた。

引張り目違い切り欠き法 (DNT) 用試験片の形状ならびに 寸法は, 基本的にはASTM C1292-95aを参考にして決定した。 試験片は, $15 \mathrm{~mm}$ 幅, $6 \mathrm{~mm}$ 厚, $30 \mathrm{~mm}$ 長さで, $0.5 \mathrm{~mm}$ 厚で $3.1 \mathrm{~mm}$ 深 さの目違い切り欠きを $15 \mathrm{~mm} \times 30 \mathrm{~mm}$ の両面に各 1 本ずつ, 切 り欠き間隔 $6 \mathrm{~mm}$ で入れた4。

\section{2 剪断試験}

標準的なインストロン型材料試験機 (AG-100kNG, 島津製 作所)ならびに計装化シャルピー衝撃試験機 (Resil25, CEAST Inc.)を用いて,DNTにより剪断試験を行った。Fig.1にシャル ピー衝撃試験機用に開発した引張りDNT用治具とストライカ 一を示す。罒中の治具の (a), (b) をストライカーの (a), (b) が たたく機構になっている。剪断強度は, 最大荷重および公称 剪断破壊面積 $\left(6 \times 15 \mathrm{~mm}^{2}\right)$ から算出した。

* Corresponding Author, E-mail: y.tanabe@rlem.titech.ac.jp 東京工業大学応用セラミックス研究所：テ226-8503 横浜市緑区長津田町4259 Materials and Structures Laboratory, Tokyo Institute of Technology : 4259 Nagatsuta, Midori, Yokohama 226-8503, Japan 


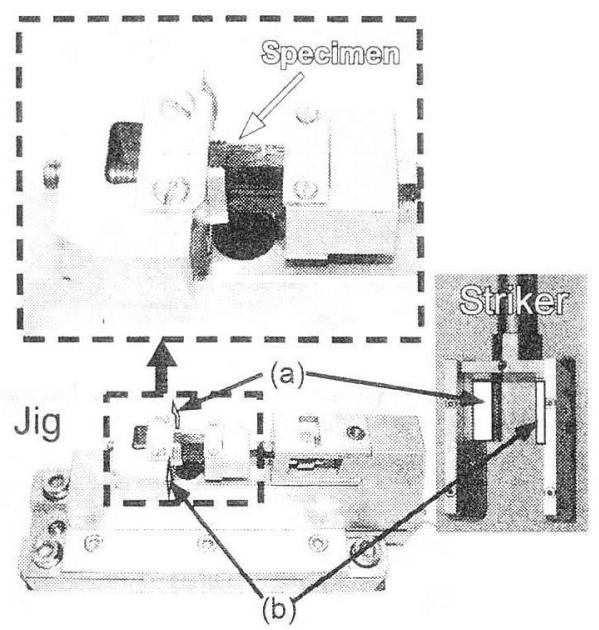

Fig.1 Specimen holding jig and striker for tensile loading on a double notched specimen. The portions of (a) and (b) on the striker hit the portions of $(a)$ and $(b)$ on the jig, respectively.

本報告では,シャルピー衝撃試験機を用いた場合は試料を 打撃する直前のストライカーの速度を, 材料試験機を用いた 場合はクロスヘッド速度を,切り欠き間隔で割った值を歪速 度とした。

\section{3 亀裂進展速度の訫測}

切り欠き間にクラックゲージ (KV-5C, 共和電業(林) を貼り 自作の高速アンプを用いて, 試験中の亀裂進展速度の計測を 行った。

\section{3. 結果と考察}

Fig.2に歪速度617/sならびに5.5×10-4/sにおいて得られた 一方向強化 $\mathrm{C} / \mathrm{C}$ 複合材料の荷重と時間との関係を示す。初期 段階を除くと直線的に荷重が負荷されている様子がわかる。 今回用いた治具とストライカーを用いて一定の負荷速度で DNT試駘を行うことができることがわかった。

Fig.3に各試料の歪速度とILSSとの関係を示す。CP-C/Cは, 歪速度が大きくなるとILSSが増加する傾向が認められたが， UD-C/Cのそれは一定であった。歪速度が大きな場合, UDTyrano, CP-Tyrano, ともにILSSは減少した。

亀裂の進展速度は, 初期には遅く, 加速され, 最終段階で減 速することがわかった。クラックゲージを用いて得られた

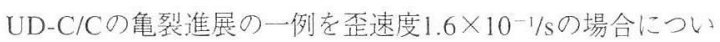
て荷重変化とともにFig.4に示す。なお, 龟裂の谁展開始を時 間ゼロとした相対時間で示してある。クラックゲージの進展 量と時間との関係から計測される亀裂進展の平均最大速度 (亀裂長さと時間との関係の傾きに相当) は, 歪速度とともに 上昇した。歪速度 $1.6 \times 10^{-5} / \mathrm{s}$ では $480 \mathrm{~m} / \mathrm{s}$ 程度であったが, $1.6 \times 10^{-1} / \mathrm{s}$ では $1,400 \mathrm{~m} / \mathrm{s}$ に達していることがわからた。し かし，こ机以上の歪速度の試験ではクラックゲージの出力が

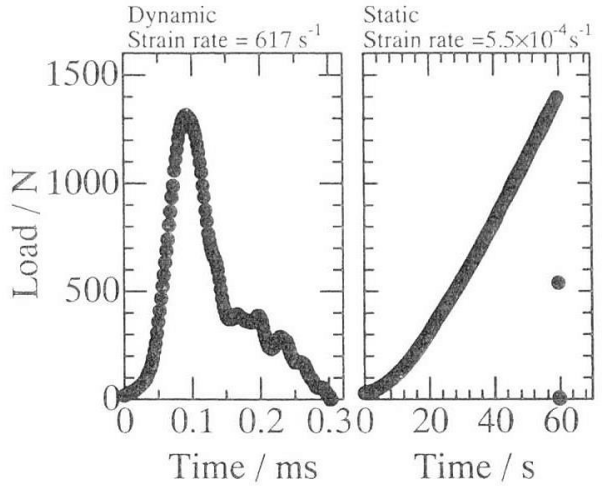

Fig.2 Load-Time curves for the unidirectional $\mathrm{C} / \mathrm{C}$ composite (UD-C/C) in static and dynamic loadings.

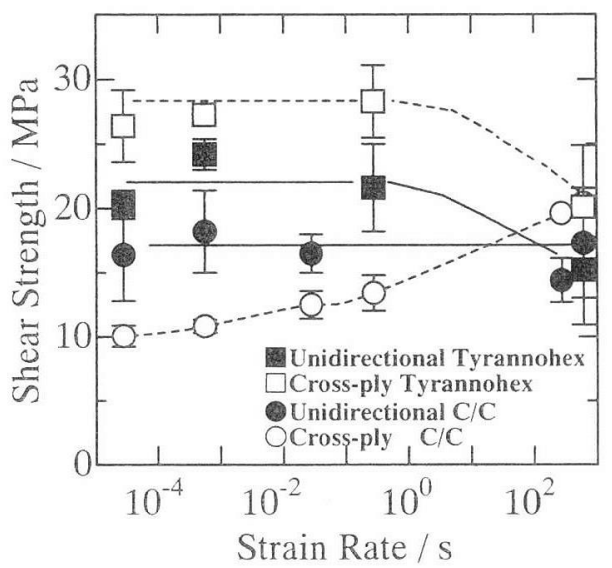

Fig.3 ILSS of $\mathrm{C} / \mathrm{C}$ composites and Tyrannohex as a function of strain rate.

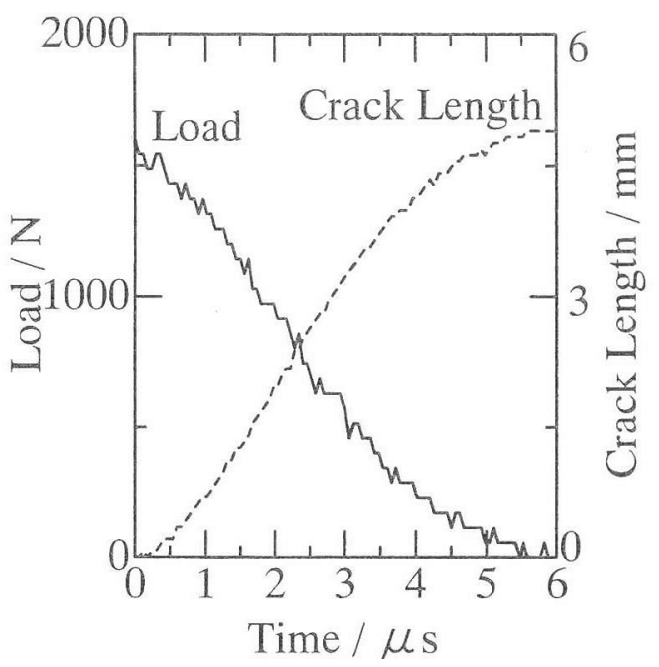

Fig.4 Crack length and load of a unidirectional C/C composite (UD-C/C) as a function of time at a strain rate of $1.6 \times 10^{-1 / \mathrm{s}}$. 
途中で追随できなくなり亀裂の進展速度を計測することがで きなかった。

歪速度が増大するにしたがい, ILSSが大きくなったCP-C/C の破面を走査型電子顕微鏡で観察したところ, 歪速度が大き い条件で破壊した試料のほうが破面の凹凹が大きかった。歪 速度の大きな領域でILSSが小さくなったUD-Tyranoおよび CP-Tyranoは, 歪速度が大きい条件では凹凸が観察されなくな る傾向が認められた。

$\mathrm{SiC} / \mathrm{SiC}$ 複合材料の繊維配向方向の引張り強度 (応力一歪曲 線における最大応力值) が, 歪速度 $10^{-4} \sim 200 /$ 範囲において 歪速度の増加とともに増加することが報告されている”。さ らに, 表面処理剤によって,この増加の割合に違いが出ること が報告1 されており，興味哚い。圧縮ではあるが, 0 は $1+35^{\circ} /$ 一 $35^{\circ}$ に編まれた織物を積層した二次元C/C複合材料におい ても同様に, 歪速度を大きくすると強度 (応力一歪曲線におけ る最大応力值) が増加し, 最大応力値を示す歪が高歪側にずれ ることが, 報告されているッ。これらの報告から, 繊維軸方向 強度において繊維の引き抜けあるいは剥離,つまり界面が高 歪速度域において荷重の最大值を決定する重要な役割を演じ ていることが示唆される。ILSSでは, 亀裂の進展方向が繊維 配向方向と平行であり報告にある亀裂の進展方向とは異な
る。しかし, 歪速度の増加とともに強度が増加した $\mathrm{CP}-\mathrm{C} / \mathrm{C} に$ おいて破面の凹凸が増加したこと, UD-Tyrano, CP-Tyranoと もに高歪速度では比較的凹凸が観察されなくなることを考え あわせると, 界面あるいは積層間での亀裂の生成（剥離）挙 動が, ILSSの歪速度依存性に何らかの影響を及ほしているこ とが示唆される。

\section{謝 辞}

本研究の一部は, 文部科学省科学研究費補助金 (No. 10450249）によった。宇部興産(侏加らチラノヘックスの提供 を受けました。感謝いたします。

\section{文 献}

1) M. Futakawa, Y. Tanabe, T. Wakui, H. Kogawa, R. Hino and M. Eto, Int. J. Impact Engng. 25 (2001) 29-40.

2) G. Subhash, S. Sulibhavi and M. A. Zikry, Composite A32 (2001) 1583-1591.

3) Y. Ishiguro, T. Akatsu, Y. Tanabe and E. Yasuda, CSJ Series 3, TTP, Switzerland (1999) pp.171-174.

4) Y. Ishiguro, T. Akatsu, Y. Tanabe, E. Yasuda, K. Maruyama and S. Yamada, Materials Science and Engineering Serving Society, Ed., S. Somiya, R. P. H. Chang, M. Doyama, R. Roy, Elsevier (1998) pp.285-288. 